\title{
EKOSISTEM PENDIDIKAN DAN PENGARUHNYA TERHADAP KEMATANGAN EMOSI SISWA DI SMA NEGERI 1 MUARO JAMBI
}

\begin{abstract}
Helmi $^{4}$
Abstract: Theaims of this study areto find out: 1) the influence of educational ecosystem on the students' emotional maturity 2) the influence of family education on the students' emotional maturity 3) the influence of school education on the students' emotional maturity, and 4) the influence of public education on the students' emotional maturity. This research was correlational research with quantitative approach. This research used a survey method with a questionnaire, which contained a series of questions about a problem or field to be studied. The sample comprised of 47 students, which were randomly taken from the Class XII IPA as the population. The data analysis used simple linear regression analysis. The result revealedthat there was the correlation between the educational ecosystem and the students' emotional maturity. From the result of the data, family education was the most influencingfactor on the students' emotional maturity in the school. Itwas around $12.72 \%$ students in the low category but sure. Mean while, the result of the school education was almost the same as theresult of public education.Both were in the lower effect on the students' emotional maturity in SMA Negeri 1 Muaro Jambi. They were around $7.43 \%$ and $7.15 \%$ studentsin a low category but defined.
\end{abstract}

Keywords: Educational Ecosystems, Emotional Maturity

${ }^{4}$ Guru SMA Negeri 1 Muaro Jambi 


\section{PENDAHULUAN}

Pada hakekatnya pendidikan merupakan suatu usaha yang dilakukan oleh manusia untuk meningkatkan taraf hidup kearah yang lebih sempurna. Pendidikan juga merupakan suatu kekuatan dinamis yang sangat berpengaruh terhadap perkembangan fisik, mental, etika dan seluruh aspek kehidupan manusia. Pendidikan adalah salah satu faktor yang besar peranannya bagi kehidupan bangsa karena pendidikan dapat mendorong dan menetukan maju mundurnya proses pembangunan bangsa dalam segala bidang.

Dalam Proses Belajar Mengajar (PBM) sangat memerlukan peran aktif guru dalam memberikan pengetahuan bagi para muridnya, sehingga menghasilkan peserta didik yang berhasil guna dan siap untuk melanjutkan kejenjang pendidikan yang lebih tinggi. Disamping itu, materi/bahan ajar yang diberikan harus memperhatikan keadaan masyarakat setempat. Sebagaimana diatur dalam Pasal 1 ayat (2) Undang-undang Nomor 20 Tahun 2003 tentang Sistem Pendidikan Nasional: "Pendidikan Nasional adalah pendidikan yang berakar pada kebudayaan bangsa Indonesia yang berdasarkanpada Pancasila dan Undang-Undang Dasar 1945”.

Efendi(2012:17) mengungkapkan belajar adalah suatu proses perubahan perilaku atau kecakapan manusia berbakat dan interaksi antara individu dengan individu dan individu dengan lingkungannya, sehingga mereka lebih mampu berinteraksi dengan ekosistemnya.

EkosistemPendidikan merupakan factor penting dalam membangun kematangan emosisiswa. Pendidikan bukan saja merupakan proses belajar mengajar di sekolah tetapi semua hal yang berhubungan dengan ilmu pengetahuan yang dapat merubah seseorang yang sebelumnya tidak baik menjadi baik, yang sebelumnya tidak bagus menjadi bagus, yang sebelumnya tidak tahu menjadi tahu. Itu semua bukan hanya didapatkan di sekolah saja tetapi disemua tempat termasuk dalam keluarga dan di masyarakat.

Dari semua itu tujuan dari setiap komponen yang terdapat dalam ekosistem pendidikan tersebut adalah mematangkan emosi siswa sehingga terbentuklah emosi yang baik dan benar terhadap diri siswa. Sebagian besar waktu yang tersedia harus digunakan oleh siswa untuk belajar, di sekolah bukan hanya belajar mata pelajaran saja yang diutamakan oleh guru kepada siswa tetapi ada hal lain yang harus guru perhatikan adalah bagaimana caranya mematangkan emosi siswa sehingga siswa dapat mengontrol emosi yang ia perlihatkan.

Seharusnya ekosistem pendidikan ini harus saling beriringan atau saling memitrakan antara satu dengan yang lain,yang mana di dalam ekosistem tersebut harus ada kerjasama antara satu dengan yang lainnya. Sekolah, keluarga, masyarakat harus bekerjasama dalam membentuk kematangan emosi siswa, kalau sampai di dalam ekosistem tersebut ada salah satu yang tidak bermitra dengan yang lainnya maka itu kemungkinan besar akan membentuk emosi yang salah terhadap siswa atau seperti emosi yang berlebihan, sehingga emosi yang diperlihatkan 
oleh siswa akan berbeda dari yang sewajarnya.

Ekosistem pendidikan juga menjadi salah satu tolok ukur dari mutu sekolah. Tetapi fakta di lapangan banyak ditemukan ekosistem pendidikan yang tidak dioptimalkan dan dikelola dengan baik untuk itu diperlukan pemahaman dan pengaplikasian manajemen ekosistem pendidikan persekolahan berbasissekolah.

Pihak sekolah seharusnya bekerjasama dengan pihak masyarakat maupun dengan pihak keluarga yaitu kedua orang tua, barulah terbentuk suatu ekosistem pendidikan yang akan mematangkan emosi siswa. Ekosistem pendidikan (sekolah, keluarga, masyarakat) sudah pasti sangat berpengaruh terhadap kematangan emosi siswa, tetapi seberapa besar pengaruh ekosistem pendidikan tersebut untuk membentuk kematangan emosi siswa. Emosi berpengaruh besar pada kualitas dan kuantitas belajar. Emosi yang positif dapat mempercepat proses belajar dan mencapai hasil belajar yang lebih baik, sebaliknya emosi yang negatif dapat memperlambat belajar atau bahkan menghentikannya sama sekali. Menurut Hurlock dalam R.Wahab (2015:165) individu yang dikatakan dapat mengendalikan emosinya,yaitu:

a. Dapat melakukan kontrol diri yang bisa diterima secara sosial.

Individu yang emosinya matang mampu mengontrol ekpresi yang tidak dapat diterima secara sosial atau membebaskan diri dari energy fisik dan mental yang bertahan dengan cara yang dapat diterima secara sosial.

b. Pemahaman diri individu yang matang, belajar memahami seberapa banyak kontrol yang dibutuhkannya untuk memuaskan kebutuhannya dan sesuai dengan harapan masyarakat.

c. Menggunakan kemampuan krisis mental. Individu yang matang berusaha menilai situasi secara kritis sebelum meresponnya, kemudian memutuskan bagaimana cara bereaksi terhadap situasi tersebut.

Penelitian ini tidak hanya menemukan besarnya pengaruh ekosistem terhadap kematangan emosi siswa secara keseluruhan saja, akan tetapi juga menganalisis setiap butir yang terdapat di dalam ekosistem pendidikan terhadap kematangan emosi siswa di sekolah, yaitu pendidikan keluarga, pendidikan sekolah dan pendidikan masyarakat.

\section{METODE PENELITIAN}

Penelitian ini adalah penelitian kuantitatif yang bersifat korelasional yang memiliki dua variabel yaitu variabel bebas dan variabel terikat yang menggunakan instrument (angket), angka-angka, mengolah data secara deduktif (dari umum kekhusus) sehingga menghasilkan kesimpulan yang bersifat menguji teori (Sutja,dkk.2014:85).

Metode yang digunakan adalah metode survey melalui angket (kuesioner) yang berisikan rangkaian pertanyaan mengenai sesuatu masalah atau bidang yang akan diteliti untuk memperoleh data, angket disebarkan 
kepada responden. Pada penelitian ini, yang menjadi populasi penelitian adalah siswa kelas XII IPA dan populasi responden adalah seluruh siswa di kelas XII IPA di SMA Negeri 1 Muaro Jambi Tahun Ajaran 2016/2017 yang berjumlah 153 orang yang dibagi dalam 5 kelas. Untuk jelasnya jumlah populasi dalam penelitian ini dapat dilihat pada tabel berikut:

\section{Tabel 1. Jumlah Populasi}

\section{Penelitian}

\begin{tabular}{|l|l|l|}
\hline No & Kelas & $\begin{array}{l}\text { Jumlah } \\
\text { Siswa }\end{array}$ \\
\hline 1 & XII IPA.1 & 32 orang \\
\hline 2 & XII IPA.2 & 32 orang \\
\hline 3 & XII IPA.3 & 30 orang \\
\hline 4 & XII IPA.4 & 32 orang \\
\hline 5 & XII IPA.5 & 31 orang \\
\hline & Jumlah & 157 orang \\
\hline
\end{tabular}

Teknik atau cara pengambilan sampel pada penelitian ini adalah teknik random sampling. Menurut Sutja,dkk (2017:69) sample random sampling (acak sederhana) adalah pengambilan data sembarangan yang memungkinkan setiap populasi jadi sampel, tanpa membedakan karakteristiknya. Pada teknik ini sampel bias diambil sembarangan asalkan sesuai dengan jumlah yang dibutuhkan atau ukuran yang representatif. Pada penelitian ini jumlah sampel representatif adalah 47 orang yang diperoleh dari $29,7 \%$ dari 157 siswa. Distribusinya sesuai dengan jumlah siswa perkelas.

Data tentang ekosistem pendidikan dan kematangan emosi siswa di SMA Negeri1Muaro Jambi diperoleh dari angket yang disebarkan secara langsung kepada siswa yang terpilih menjadi sampel penelitian.
Untuk mencari pengaruh ekosistem pendidikan dengan kematangan emosi dinyatakan dalam bentuk hubungan pengaruh $\mathrm{X}$ (pengaruh ekosistem pendidikan) terhadap Y (kematangan emosi).

Analisis regresi linear sederhana pada penelitian ini dilakukan secara manual/sederhana. Untuk mengetahui besarnya pengaruh variabel $\mathrm{X}$ terhadap variabel $\mathrm{Y}$ adalah dengan menggunakan indek determinasi (KD) yang dinyatakan dalam persentase.

$$
\mathrm{KD}=\mathrm{r}^{2} \times 100 \%
$$

Keterangan:

$\mathrm{KD}=$ Koefisien determinasi yang dicari

$\mathrm{r} \quad=$ korelasi variabel $\mathrm{X}$ dengan $\mathrm{Y}$ yang sudah ditemukan

Adapun kriteria penafsiran pengaruh (X tunggal) adalah sebagai berikut:

Tabel 2. Kriteria Penafsiran Pengaruh Parsial (X tunggal)

\begin{tabular}{|r|l|l|}
\hline No & $\begin{array}{l}\text { Nilai } \\
\text { Determinasi }\end{array}$ & \multicolumn{1}{|c|}{ Pengaruh } \\
\hline 1 & $0,00-0,04$ & Sangat lemah \\
\hline 2 & $0,05-0,16$ & Rendah tapi pasti \\
\hline 3 & $0,17-0,49$ & Cukup kuat \\
\hline 4 & $0,50-0,81$ & Tinggi atau kuat \\
\hline 5 & $0,82-1,00$ & $\begin{array}{l}\text { Sangat tinggi atau } \\
\text { sangatkuat }\end{array}$ \\
\hline
\end{tabular}

\section{HASIL DAN PEMBAHASAN}

Penelitian ini dilakukan untuk mengungkap pengaruh ekosistem pendidikan $(\mathrm{X})$ terhadap kematangan emosi (Y). Deskripsi data yang akan disajikan dari hasil penelitian ini adalah memberi gambaran secara umum mengenai penyebaran data masing-masing indikator yang diperoleh dilapangan. Pengamatan dilakukan dengan mengukur sejumlah 
indikator yang dijabarkan dalam bentuk kisi-kisi serta dioperasionalkan melalui pernyataanpernyataan seperti yang tertera pada Tabel 3.

Berdasarkan hasil pengolahan data yang dihitung dengan menggunakan rumus regresi linear, maka pengaruh ekosistem pendidikan dengan kematangan emosi siswa di SMA Negeri 1 Muaro Jambi seperti tertera pada Tabel 4.

Dari hasil perhitungan dengan persamaan regresi linear yang diperoleh secara manual adalah $\mathrm{Y}=$ $18,43+0,233$ X. Persamaan regresi linear sederhana ini memberikan prediksi bahwa ekosistem memiliki pengaruh yang rendah tapi pasti terhadap kematangan emosi siswa di sekolah. Dengan adanya dukungan dari ekosistem pendidikan, maka hasil kematangan emosi secara konstan berada pada18,43. Selanjutnya untuk mengetahui besarnya pengaruh variabel $\mathrm{X}$ terhadap variabel $\mathrm{Y}$ adalah dengan menggunakan indek determinasi (KD) yang dinyatakan dalam persentase. Hasil yang diperoleh dengan menggunakan rumus indek determinasi adalah $5,4 \%$.

Hasil perhitungan dapat dijelaskan bahwa ada pengaruh variabel $\mathrm{X}$ terhadap $\mathrm{Y}$ sebesar $5,4 \%$. Dengan kata lain dapat diartikan bahwa 5,4\% dari variabel kematangan emosi (Y) dipengaruhi oleh variabel ekosistem pendidikan (X). Jika dilihat dari tabel penafsiran pengaruh parsial (X tunggal), menurut Sutja dkk
(2017:100) nilai determinasi yang berada pada angka 0,05-0,16 ditafsirkan memiliki pengaruh yang rendah tapi pasti.

Pada Tabel 5 dapat dilihat analisa setiap butir yang terdapat di dalam ekosistem pendidikan. Berdasarkan Tabel 4 diketahui nilai $r$ untuk pengaruh pendidikan keluarga terhadap kematangan emosi siswa (diolah dengan menggunakan Microsoft excel 2010) adalah $\mathrm{r}=0,13$ dengan nilai $\mathrm{KD}=12,72 \%$. Dapat disimpulkan bahwa ada pengaruh pendidikan keluarga terhadap kematangan emosi. Hasil pencarian koefisien determinasi adalah $12,72 \%$ berada pada kisaran angka $0,05-0,16$ yang artinya pengaruh pendidikan keluarga terhadap kematangan emosi siswa adalah rendah tapi pasti.

Untuk pengaruh pendidikan sekolah terhadap kematangan emosi siswa adalah $\mathrm{r}=0,074$ hasil $\mathrm{KD}$ adalah $7,43 \%$ berada pada kisaran $0,05-0,16$ yang artinya pengaruh pendidikan sekolah terhadap kematangan emosi siswa juga rendah tapi pasti.

Untuk pengaruh pendidikan masyarakat terhadap kematangan emosi siswa (diolah dengan menggunakan Microsoft excel 2010) adalah $\mathrm{r}=0,071$, nilai $\mathrm{KD}$ adalah $7,15 \%$. Hasil pencarian ini juga berada pada kisaran $0,05-0,16$ yang artinya pengaruh pendidikan masyarakat terhadap kematangan emosi siswa juga rendah tapi pasti. 


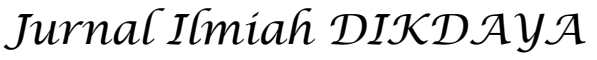

Tabel 3. Kisi-Kisi Angket Variabel Ekosistem Pendidikan

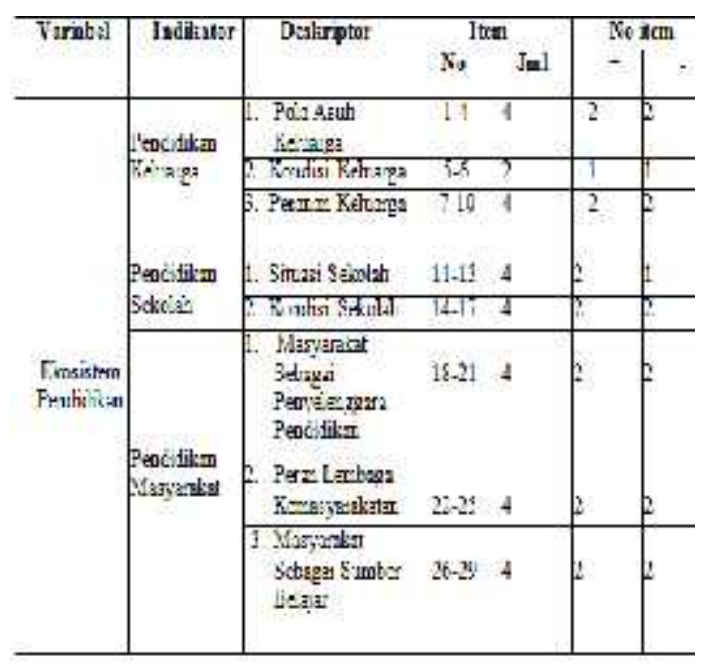

Tabel

4. Skor

Ekosistem

Pendidikan terhadap Emosi (KE)

\begin{tabular}{|c|c|c|c|c|c|}
\hline \multirow{4}{*}{$\begin{array}{c}\text { Res } \\
\text { p }\end{array}$} & \multicolumn{2}{|c|}{ Skor } & \multirow{4}{*}{$\begin{array}{c}\text { Res } \\
\text { p }\end{array}$} & \multicolumn{2}{|c|}{ Skor } \\
\hline & $\mathbf{E}$ & $\mathbf{E}$ & & EP & EK \\
\hline & $\mathbf{P}$ & $\mathbf{K}$ & & & \\
\hline & $\mathrm{X}$ & $\mathrm{Y}$ & & $X$ & $\mathrm{Y}$ \\
\hline 1 & 20 & 22 & 25 & 18 & 21 \\
\hline 2 & 15 & 24 & 26 & 23 & 26 \\
\hline 3 & 15 & 25 & 27 & 17 & 24 \\
\hline 4 & 19 & 25 & 28 & 17 & 19 \\
\hline 5 & 20 & 23 & 29 & 23 & 25 \\
\hline 6 & 21 & 23 & 30 & 19 & 23 \\
\hline 7 & 17 & 23 & 31 & 20 & 21 \\
\hline 8 & 22 & 24 & 32 & 17 & 17 \\
\hline 9 & 17 & 26 & 33 & 23 & 26 \\
\hline 10 & 21 & 21 & 34 & 24 & 28 \\
\hline 11 & 18 & 22 & 35 & 19 & 19 \\
\hline 12 & 15 & 23 & 36 & 21 & 23 \\
\hline 13 & 20 & 28 & 37 & 19 & 21 \\
\hline 14 & 22 & 25 & 38 & 21 & 25 \\
\hline 15 & 23 & 21 & 39 & 22 & 22 \\
\hline 16 & 18 & 21 & 40 & 18 & 23 \\
\hline 17 & 20 & 26 & 41 & 16 & 23 \\
\hline 18 & 19 & 20 & 42 & 21 & 20 \\
\hline 19 & 17 & 24 & 43 & 24 & 25 \\
\hline 20 & 21 & 27 & 44 & 17 & 21 \\
\hline
\end{tabular}

\begin{tabular}{|c|c|c|c|c|c|}
\hline 21 & 13 & 25 & 45 & 19 & 21 \\
\hline 22 & 18 & 21 & 46 & 21 & 22 \\
\hline 23 & 19 & 21 & 47 & 20 & 21 \\
\hline 24 & 17 & 21 & & & \\
\hline & & & $\begin{array}{l}\text { Jumla } \\
\text { h }\end{array}$ & 906 & 1077 \\
\hline & & & Rerata & $\begin{array}{c}19,2 \\
8\end{array}$ & $\begin{array}{c}22,9 \\
1\end{array}$ \\
\hline & & & Maks & 25 & 28 \\
\hline & & & Min & 13 & 17 \\
\hline
\end{tabular}

Tabel 5. Skor Pendidikan Keluarga (PK), Pendidikan Sekolah (PS) dan Pendidikan Masyarakan (PM) terhadap Kematangan Emosi

\begin{tabular}{|c|c|c|c|c|c|c|}
\hline \multirow{2}{*}{ Resp } & \multicolumn{2}{|c|}{ Skor } & \multicolumn{2}{c|}{ Skor } & \multicolumn{2}{c|}{ Skor } \\
\cline { 2 - 7 } & PK & KE & PS & KE & PM & KE \\
\cline { 2 - 7 } & $\mathbf{X}$ & $\mathbf{Y}$ & $\mathbf{X}$ & $\mathbf{Y}$ & $\mathbf{X}$ & $\mathbf{Y}$ \\
\hline 1 & 10 & 22 & 5 & 22 & 5 & 22 \\
\hline 2 & 8 & 24 & 4 & 24 & 3 & 24 \\
\hline 3 & 5 & 25 & 4 & 25 & 6 & 25 \\
\hline 4 & 6 & 25 & 6 & 25 & 7 & 25 \\
\hline 5 & 7 & 23 & 6 & 23 & 7 & 23 \\
\hline 6 & 7 & 23 & 6 & 23 & 8 & 23 \\
\hline 7 & 7 & 23 & 5 & 23 & 5 & 23 \\
\hline 8 & 8 & 24 & 7 & 24 & 7 & 24 \\
\hline 9 & 6 & 26 & 5 & 26 & 6 & 26 \\
\hline 10 & 5 & 21 & 7 & 21 & 9 & 21 \\
\hline 11 & 5 & 22 & 6 & 22 & 7 & 22 \\
\hline 12 & 6 & 23 & 5 & 23 & 4 & 23 \\
\hline 13 & 7 & 28 & 5 & 28 & 8 & 28 \\
\hline 14 & 8 & 25 & 6 & 25 & 8 & 25 \\
\hline 15 & 9 & 21 & 6 & 21 & 8 & 21 \\
\hline 16 & 6 & 21 & 6 & 21 & 6 & 21 \\
\hline 17 & 7 & 26 & 6 & 26 & 7 & 26 \\
\hline 18 & 7 & 20 & 5 & 20 & 7 & 20 \\
\hline 19 & 5 & 24 & 6 & 24 & 6 & 24 \\
\hline 20 & 6 & 27 & 6 & 27 & 9 & 27 \\
\hline 21 & 5 & 25 & 4 & 25 & 4 & 25 \\
\hline 22 & 8 & 21 & 5 & 21 & 5 & 21 \\
\hline 23 & 7 & 21 & 7 & 21 & 5 & 21 \\
\hline 24 & 6 & 21 & 6 & 21 & 5 & 21 \\
\hline 25 & 6 & 21 & 6 & 21 & 6 & 21 \\
\hline
\end{tabular}




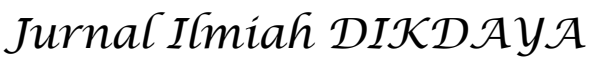

\begin{tabular}{|c|c|c|c|c|c|c|}
\hline 26 & 8 & 26 & 7 & 26 & 8 & bata \\
\hline 27 & 5 & 24 & 6 & 24 & 6 & l2etmatangan emosi (Y) dipengaruhi \\
\hline 28 & 6 & 19 & & 9 & 6 & bel ekosis \\
\hline 29 & 9 & 25 & 0 & 5 & 8 & (X5). \\
\hline 30 & 7 & 23 & 6 & 23 & 6 & Mengacu pada \\
\hline 31 & 7 & 21 & 6 & 21 & 7 & penafpiran pengaruh parsial \\
\hline 32 & 5 & 17 & & 7 & 6 & tuthggal) yang dikemukan oleh Sutja \\
\hline 33 & 9 & 26 & & 6 & 9 & dyle (2017:100) nilai 0,054 tersebut \\
\hline 34 & 8 & 28 & 7 & 8 & 9 & berada pada pengaruh \\
\hline 35 & 7 & 19 & 5 & 19 & 1 & pasti, hal \\
\hline 36 & 6 & 23 & & 23 & 8 & determinan berada \\
\hline 37 & 6 & 21 & 7 & 21 & 6 & \\
\hline 38 & 7 & 25 & 7 & 25 & 7 & yang pos \\
\hline 39 & 8 & 22 & 6 & 22 & 8 & pendrdikan ter \\
\hline 40 & 5 & 23 & 6 & 23 & 1 & \\
\hline 41 & 5 & 23 & 6 & 23 & 5 & t3ens \\
\hline 42 & 8 & 20 & 5 & 20 & 8 & lapar \\
\hline 43 & 10 & 25 & 7 & 25 & 7 & 25 skipun terlihat \\
\hline 44 & 5 & 21 & 5 & 21 & 7 & pendidikan yang menjurus kepada \\
\hline 45 & 7 & 21 & 5 & 21 & 7 & perilaku yang negative bukan berarti \\
\hline 46 & 6 & 22 & 5 & 22 & 10 & ekosistem pendi \\
\hline 47 & 5 & 21 & 5 & 21 & 10 & Phemberikan pengaruh yang negative \\
\hline Jumlah & 16 & 1077 & 270 & 1077 & 320 & $197 \bar{z}$ pada kematangan emosinya. \\
\hline Rerata & 6,72 & 22,91 & 5,74 & 22,91 & 81 & 22,91 Hasil penelitian \\
\hline Max. & 10 & 28 & 7 & 28 & 10 & 288mbuktikan pandangan $\mathrm{Kh}$ \\
\hline Min. & 5 & 17 & 4 & 17 & 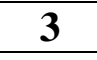 & (LD11):155) suasana lingkungan s \\
\hline $\begin{array}{l}\text { engaruh } \\
\text { mosi sis } \\
\text { ambi } \\
\text { orelasi } \\
\text { iolah m } \\
\text { inear se } \\
\text { esarnya } \\
\text { erhadap } \\
\text { engolah } \\
\text { esponder } \\
\text { etermin } \\
\text { erhitung } \\
\text { isimpull } \\
\text { engaruh } \\
\text { terhad }\end{array}$ & $\begin{array}{l}\text { nya } \\
\text { wa di } \\
\text { ditem } \\
\text { yang } \\
\text { enggu } \\
\text { derha } \\
\text { per } \\
\text { Y. } \\
\text { an an } \\
\text { ter } \\
\text { asi t } \\
\text { an t }\end{array}$ & $\begin{array}{l}\text { arkan } \\
\text { pend } \\
\text { terhad } \\
\text { SMA } \\
\text { ukan } \\
\text { rendah } \\
\text { anakan } \\
\text { na un } \\
\text { ngaruh } \\
\text { Has } \\
\text { gket ya } \\
\text { sebut } \\
0,054 \\
\text { ersebu } \\
\text { bah } \\
\text { berart } \\
\text { riabel } \\
\text { lain }\end{array}$ & $\begin{array}{l}1 \quad \text { ak } \\
\text { ing dii } \\
\text { diperc } \\
(5,40 \\
\text { t, ma }\end{array}$ & $\begin{array}{l}\text { iabel } \\
\text { hir d } \\
\text { si oleh } \\
\text { leh ni } \\
\text { o). D } \\
\text { ka dap } \\
\text { terda }\end{array}$ & & $\begin{array}{l}\text { lingkungan keluarga maupun } \\
\text { lingkungan masyarakat sekitar yang } \\
\text { berhubungan dengan proses-proses } \\
\text { sosialisasi yang dapat membentuk } \\
\text { seseorang menjadi pribadi yang } \\
\text { matang. Sejalan dengan pandangan } \\
\text { Khairani di atas Ki Hajar Dewantara } \\
\text { (Hasbullah, 2012:37) menganggap } \\
\text { ketiga lembaga pendidikan tersebut } \\
\text { sebagai tri pusat pendidikan. } \\
\text { Maksudnya, tiga pusat pendidikan } \\
\text { yang secara bertahap dan terpadu } \\
\text { mengemban suatu tanggung jawab } \\
\text { pendidikan bagi generasi mudanya. } \\
\text { Hasil penelitian yang menunjukkan } \\
\text { adanya pengaruh ekosistem } \\
\text { pendidikan terhadap kematangan } \\
\text { emosi siswa di SMA Negeri } 1 \text { Muaro } \\
\text { Jambi ini membuktikan bahwa }\end{array}$ \\
\hline
\end{tabular}


pengaruh yang disumbangkan oleh ekosistem pendidikan bukan saja berupa pengaruh yang bersifat negatif tetapi juga bersifat positif.

\section{KESIMPULAN}

Berdasarkan hasil penelitian ekosistem pendidikan dan pengaruhnya terhadap kematangan emosi siswa di SMA Negeri 1 Muaro Jambi yang telah dilakukan berada pada kategori rendah tapi pasti. Artinya terdapat pengaruh yang berarti antara variabel $\mathrm{X}$ (ekosistem pendidikan) terhadap variabel $\mathrm{Y}$ (kematangan emosi siswa). Kondisi tersebut dapat dilihat dari nilai variabel $\mathrm{X}$ terhadap variabel $\mathrm{Y}$ sebesar $5,4 \%$ yang berada pada kisaran angka 0,05-0,16 (rendah tapi pasti). Untuk nilai skor masingmasing indikator adalah sebagai berikut:

1. Pengaruh keluarga

pendidikan kematangan emosi siswa di sekolah adalah 12,72\% berada pada kisaran angka 0,05-0,16 berarti pengaruh pendidikan keluarga terhadap kematangan emosi siswa di sekolah adalah rendah tapi pasti.

2. Pengaruh pendidikan sekolah terhadap kematangan emosi siswa di sekolah adalah $7,43 \%$ berada pada kisaran angka $\quad 0,05-0,16$ berarti pengaruh pendidikan sekolah terhadap kematangan emosi siswa di sekolah juga rendah tapi pasti.

3. Pengaruh pendidikan masyarakat terhadap kematangan emosi siswa di sekolah adalah $7,15 \%$ berada pada kisaran angka 0,05-0,16 berarti pengaruh pendidikan masyarakat terhadap kematangan emosi siswa di sekolah adalah rendah tapi pasti.

Dari hasil penelitian yang telah dipaparkan di atas secara umum pendidikan keluarga paling mempengaruhi kematangan emosi siswa di sekolah yaitu12,72\%, sedangkan pendidikan sekolah dan pendidikan masyarakat hampir berimbang dengan nilai lebih rendah pengaruhnya terhadap kematangan emosi siswa di SMA Negeri 1 Muaro Jambi yaitu 7,43\% dan 7,15\% .

\section{DAFTAR PUSTAKA}

Gulo, W. 2010. Metodologi

Penelitian. Jakarta: PT Gramedia.

Hurlock E.B. 2015. Psikologi

Perkembangan. Jakarta: Erlangga.

Hadi, H. 2001. Analisis

Regresi.Yogyakarta: Andi.

Hurlock E.B. 2015. Psikologi

Perkembangan. Jakarta: Erlangga.

Khairani M. 2016. Psikologi Umum. Yogyakarta: Aswada Pressindo.

Sugiyono. 2014. Metode Penelitian Kuantitatif Kualitatif dan $R \& D$. Bandung: Alfabeta.

Sutja, A. dkk. 2017. Penulisan Skripsi untuk Prodi Bimbingan Konseling. Yogyakarta: Writing Revolution.

Triwiyanto, T. 2015. Pengantar Pendidikan. Jakarta: PT Bumi Aksara 